\title{
Effect of Career, Employee Engagement, and Compensation of Behavior Organisational Citizenship in PT. Wika Intinusa Surabaya
}

\author{
Dhitanayu Cakrawardani $\mathrm{a}^{\mathrm{a}^{*}}$, Bayu Airlangga Putra ${ }^{\mathrm{b}}$, Mochamad Arif ${ }^{\mathrm{c}}$ \\ ${ }^{a}$ Faculty of Economics anda Business, Narotama University, Surabaya, Indonesia \\ ${ }^{b}$ Faculty of Economics anda Business, Narotama University, Surabaya, Indonesia \\ ${ }^{c}$ Faculty of Economics anda Business, Narotama University, Surabaya, Indonesia
}

\begin{abstract}
This study discusses how career influence, employee involvement, and compensation towards organizational Citizenship Behavior in PT Wika Intinusa Surabaya. This study aims to determine the effect of career, employee involvement, compensation on organizational Citizenship Behavior. The sampling technique in this study is to use the census method. Respondents in this study were 50 active employees in the city of Surabaya. The data analysis method uses multiple linear regression test, with SPSS v.1.8 software as an analysis tool. The results of this study indicate that the variable Career and variable compensation partially affects the Organizational Citizenship behavior, but in Variable Employee Engagement (Employee Engagement) less influential partially on Organizational Citizenship Behavior.
\end{abstract}

Keyword: Career, Employee Engagement, Compensation, Organizational Citizenship Behavior.

\section{Introduction}

Human resources are elements that move towards an organization, where the organization can achieve a certain goal. For an organization where human resources are a subject that plays a very important role, therefore they are the managers and regulators of the course of a job in an organization. In the current era of globalization, business entities must be cooperative in responding to the very tight competition in taking a policy. But the company must be able to highlight the unity - oneness for the progress of the company. In this company is engaged in chemical and general suppliers branched out in West Surabaya.

In a company there must be a career that can support employee performance, but in this problem employees who have worked only with the employment contract system for a short time. And this employee is trying to work very well but the work contract that has been given by the company is not extended by the company. So this employee has to repeat his career from the beginning and have to look for work again.

And also there is no direct involvement with employees because the opinions given by the employees are only not in accordance with what is desired by the company. Therefore few employees quit the job.

Conversely, there are employees who work that are not in accordance with the work they have undertaken. However, there are also employees who are willing to give their time only for the progress of the company and for the problem of compensation to these employees only given not in accordance with employee expectations.

\footnotetext{
* Corresponding author.

E-mail address: dhitaicha@gmail.com (Dhitanayu Cakrawardani)
} 
Based on the phenomena that occur at this time it is very important an attachment or a sense of kinship between employees and superiors in the company in order to be able to carry out their obligations together in building a more advanced company in the future.

In a company sometimes employees make mistakes or managers make mistakes, but it can mature employees in making decisions, which all things can be discussed well - both with the two parties or concerned. In a company must also have a commitment to work with employees, so that the company can run better in the present and the future.

Table 1 Employee expectations in PT Wika Intinusa Surabaya

\begin{tabular}{llll}
\hline Information & 2017 & 2018 & 2019 \\
\hline Contract employees & 15 & 9 & 6 \\
Permanent employees & 118 & 109 & 89 \\
\hline
\end{tabular}

Source: PT Wika Intinusa Surabaya , 2019

In order for employees to stay in the company and enjoy doing work in accordance with their position, managers should be able to provide something in the form of goods or gifts, manager support and motivation from managers, so that employees can be more active in working. Organizations within the company must be able to run well and as a manager must be able to lead and be a role model for their employees. And also managers must be able to provide compensation to employees such as career clarity and career worthiness while working well for the company. Which is where in the GAP the results are significant for a company that has been examined previously.

Organ believes that OCB is an extra individual behavior, which is not directly or explicitly recognized in a formal work system, and which in the aggregate can increase the effectiveness of organizational functions. Then for further research to formulate OCB deeper, namely the contribution to the maintenance and improvement of the social and psychological context of task support Nielsen (2012).

Like PT Wika Intinusa Surabaya, which is engaged in services, which has the aim of improving the quality of its human resources, one of which is to enhance careers in employee engagement and also receive compensation for efforts to meet employee performance so that company resources meet the company's needs so able to anticipate all obstacles that will arise in the company. in the company there is organizational citizenship behavior in which employees are willing to help the work of fellow employees who are in distress and can also provide energy and thoughts to employees who have been helped.

Careers are very important for employees at PT Wika Intinusa, because of how many employees will be promoted and get compensation that is the size to assess employees at the company. Companies should be able to ensure career paths, employee engagement and compensation for the organization of employee citizenship behavior that can determine the performance results of employees who come from within the country and employee commitment to be organized in a company that will spread 50 questionnaires for employees.

In order for this researcher to become focused it needs to be raised about the research objectives. Based on the formulation of the problems that exist in the existing research, the purpose of this study is to find out the influence of career clarity, employee management and the feasibility of compensation for organizational citizenship behavior in PT Wika Intinusa.

From the description of the above background, this study is interested in studying about a career, employee involvement (employee enggagement) and compensation for the organization citizenship behavior, so the researchers studied under the title "The Effect of Career, Employee Engagement (employee engagement), Compensation for Organisasinal Citizenship Behavior.” 


\section{Literature review}

\subsection{Career}

Career is a plan about the possibilities - the possibility of a person or members of the organization as individuals pursue the process of promotion or position in accordance with the requirements and abilities. In a career planning must be based on the preparation of the requirements that must be owned by someone, in order to support career advancement. Career planning is an important component in preparing to choose the desired further education or occupation. Career planning consists of preparing yourself and compiling a better career choice list, which can be done by increasing information about the requirements of the workforce needed, adding skills and so on. Simamora states that career planning is a process by which individuals can identify and take steps to achieve their career goals. Careers involve identifying goals related to careers and preparing plans to achieve those goals. According to Proposition S (2002:277) "career is a process that is" deliberately created the company to help employees in order boa ntu workplace participation.

\subsection{Employee engagement (employee engagement)}

According to Robinson, Perryman and Hayday (2004), Employee Engagement is a positive attitude of individual employees towards the organization and organizational values. Employees with a high level of attachment to the organization have an understanding and concern for the organization's operational environment, able to work together to improve the achievement of work units or organizations through collaboration between employees and management.

\subsection{Compensation}

Parwanto and Wahyudin (2011), who examined the influence of factors of job satisfaction on employee performance. The study obtained the results that job satisfaction factors which include salary, leadership, the attitude of co-workers have a significant influence on employee performance.

Compensation is an award that is given to employees both directly and indirectly, financially and non-financially equitably to employees for their contribution in achieving organizational goals, so that compensation is needed by any company to improve the performance of its employees. Forms of financial compensation are salary, benefits, bonuses, and commissions. And for non-financial compensation includes training, authority and responsibility, appreciation for performance and a supportive work environment (Hussein Umar, 2001: 16).

\subsection{Organizational Citizenship Behavior}

According to (Robbins, 2008), Organizational citizenship behavior is the behavior of individuals or individuals who are voluntary and not part of the formal requirements of the job, but can improve the effective functioning of the organization.

With the development of the current era of globalization, many problems arise in humans. Basically, humans can not alone in meeting their needs, he will form a group which is then called an organization. Humans are the main supporters of every organization. Human behavior in a group or organization is the beginning of organizational behavior.

According to Rivai (2012: 172) organizational behavior is a study that involves aspects of human behavior in a particular group. Meanwhile, according to Robbins and Judge (2011: 43) organizational behavior is a field of study that invests the impact of individual, group and structure behavior in organizations with the intention of applying knowledge to improve organizational effectiveness. 
Citizenship behavior in an organization or Organizational Citizenship Behavior (OCB) is a new concept in terms of performance analysis. This concept explains that OCB behavior is carried out by an individual with full freedom (at will) in determining something and mutual understanding without any requests for compensation or other formal rewards to the organization, so this behavior is very helpful and beneficial to the organization. The concept was introduced in the 1980s by Dennis Organ and continues to grow and expand.

Organ et al. (2006: 8) describe $O C B$ as individual behavior that is free (discretionary), which does not directly and explicitly get rewards from the formal reward system, and which as a whole (aggregate) increases the efficiency and effectiveness of organizational functions. Be free and voluntary, because the behavior is not required by role requirements, or a description of the position that is clearly demanded based on a contract with the organization, but as a personal choice.

\subsection{Framework of thinking}

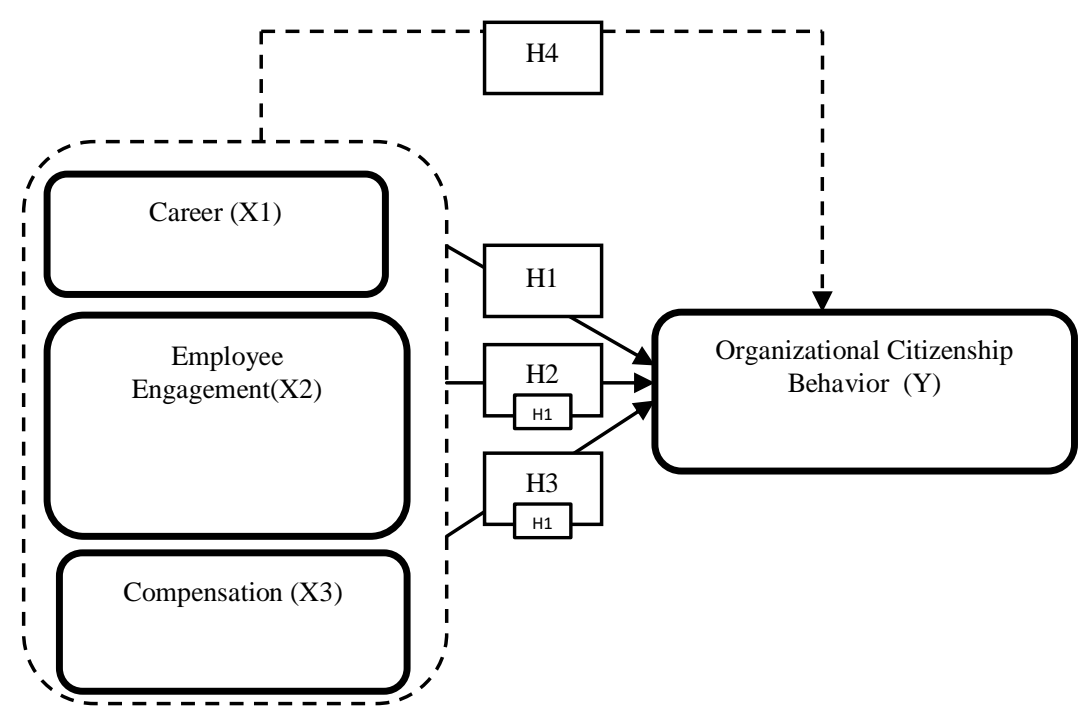

Figure 1 Framework of thinking

\subsection{Hypothesis}

Based on the formulation of the problem and description of the literature review the authors propose the following research hypotheses:

H1: Career clarity partially has a significant effect on the citizenship with citizenship.

H2: Employee Management partially has a significant effect on organizational citizenship behavior.

H3: Compliance Feasibility partially has a significant effect on organizational citizenship behavior

H4: Career clarity, employee management and the appropriateness of compensation simultaneously have a significant effect on organizational citizenship behavior.

\section{Research methods}

\subsection{Population and sample}

Analysis of the data used in this study uses quantitative descriptive analysis techniques. According to Nana Sudjana and Ibrahim (2001), the definition of quantitative research is research based on assumptions, then determined variables, and then analyzed using valid research methods, especially in quantitative research. The object of research 
is something that is the reason for doing research, the object of research is the goal to find answers and solutions to problems that occur. The object of research in this study were employees of PT Wika Intinusa Surabaya. The population in this study were 50 employees of PT Wika Intinusa Surabaya. The method used for sampling this research is to use a census sampling technique or sample jenu where all members of the population are sampled.

\subsection{Multiple linear regression analysis}

Multiple linear regression analysis is a linear relationship between two or more independent variables $\left(\mathrm{X}_{1}, \mathrm{X}_{2}\right.$, $\ldots \mathrm{X}_{\mathrm{n}}$ ) with the dependent variable $(\mathrm{Y})$. This analysis is to determine the direction of the relationship between the independent variable with the dependent variable whether each independent variable is positively or negatively related and to predict the value of the dependent variable if the value of the independent variable has increased or decreased. The data used is usually interval or ratio scale.

The multiple linear regression equation is as follows:

With:

$$
\mathrm{Y}^{\prime}=a+b_{1} \mathrm{X}_{1}+\mathrm{b}_{2} \mathrm{X}_{2}+\ldots+\mathrm{b}_{\mathrm{n}} \mathrm{X}_{\mathrm{n}}+e
$$

$\mathrm{Y}^{\prime} \quad=$ dependent variable (predicted value)

$\mathrm{X}_{1}, \mathrm{X}_{1}=$ Independent variables

$a \quad=$ Constant (value of $\mathrm{Y}$ 'if $\mathrm{X}_{1}, \mathrm{X}_{2} \ldots \mathrm{X}_{\mathrm{n}}=0$ )

$b \quad=$ Regression coefficient (increase or decrease value)

$e \quad=$ error

\section{Results and discussion}

\subsection{Test Validity and Reliability}

Data processing used in this study uses SPSS version 20.0, with the type of data obtained by being transformed from an ordinal form to an interval using the Method of Successive Intervel. To facilitate data acquisition in order to explain the results of respondents from the variables that will be examined.

Table 2 Test Validity

\begin{tabular}{lllll}
\hline \multicolumn{1}{c}{ Variabel } & Indikator & $\begin{array}{c}\text { Corrected Item- } \\
\text { Total Correlation }\end{array}$ & R-Table & Note \\
\hline \multirow{4}{*}{ Carrer (X1) } & X1.1 & 0,641 & 0,235 & Valid \\
& X1.2 & 0,524 & 0,235 & Valid \\
& X1.4 & 0,590 & 0,235 & Valid \\
& X1.5 & 0,483 & 0,235 & Valid \\
& X1.6 & 0,629 & 0,235 & Valid \\
Employee & X2.1 & 0,242 & 0,235 & Valid \\
Engagement & X2.2 & 0,740 & 0,235 & Valid \\
(X2) & X2.3 & 0,517 & 0,235 & Valid \\
& X2.4 & 0,816 & 0,235 & Valid \\
Compensation & X3.1 & 0,573 & 0,235 & Valid \\
(X3.2 & X3.2 & 0,576 & 0,235 & Valid \\
& X3.3 & 0,687 & 0,235 & Valid \\
\hline
\end{tabular}




\begin{tabular}{lllll}
\hline \multicolumn{1}{c}{ Variabel } & Indikator & $\begin{array}{c}\text { Corrected Item- } \\
\text { Total Correlation }\end{array}$ & R-Table & Note \\
\hline & X3.4 & 0,480 & 0,235 & Valid \\
& Y1 & 0,558 & 0,235 & Valid \\
Organizational & Y2 & 0,734 & 0,235 & Valid \\
Citizenship & Y3 & 0,356 & 0,235 & Valid \\
Behavior (Y) & Y4 & 0,643 & 0,235 & Valid \\
& Y5 & 0,434 & 0,235 & Valid \\
\hline
\end{tabular}

Based on the results of the validity test according to the table 2 for all dimensions states that of the 19 item questions, invalid there are invalid items. Thus the number of valid items will be used as a research data collection tool as many as 19 questions.

\subsection{Reliability test}

Table 3 Reliability Test

\begin{tabular}{c|c}
\hline \multicolumn{2}{c}{ Reliability Statistics } \\
\hline Cronbach's Alpha & N of Items \\
\hline 0,718 & 19 \\
\hline
\end{tabular}

Based on the table 3 on the reliability test above, the data of this study have a Cronbach's alpha value of 0,718 , and more than 0.5 with a question of 19 items. Then the data is declared reliable

\subsection{Classic assumption test}

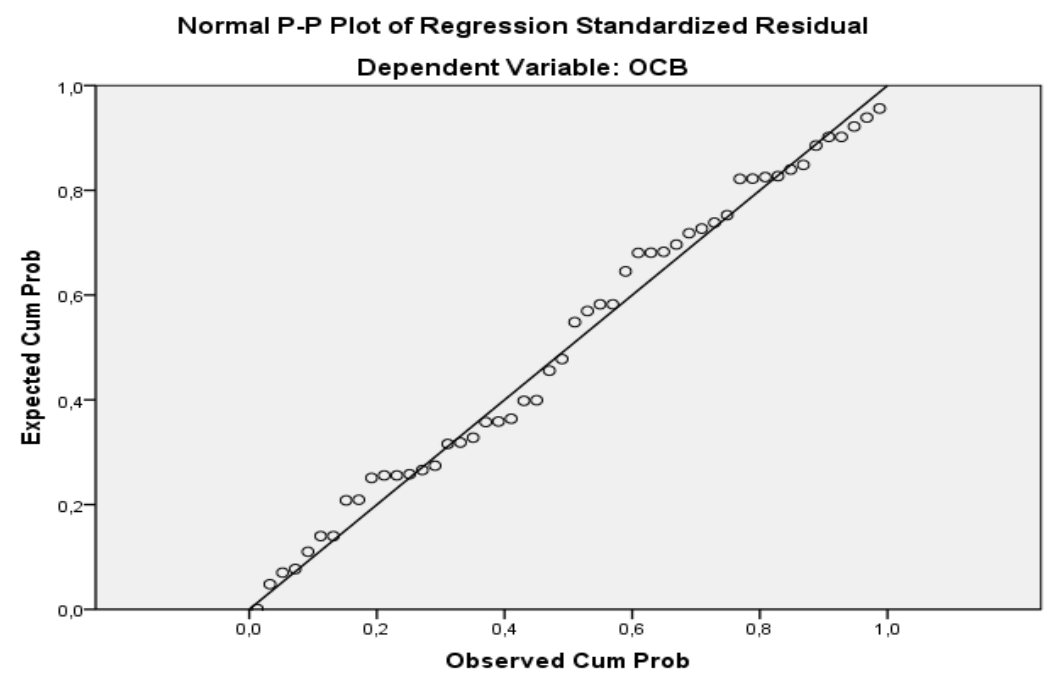

Figure 2 Normality test 
Based on the figure 2 shows that all existing data are normally distributed, because all data spread in a diagonal straight line then the data meets the normal assumption or follows the normality line.

\subsection{Multicollinearity Test}

Table 4 Multicollinearity Test

Coefficients $^{\mathrm{a}}$

\begin{tabular}{llcc}
\hline & Model & \multicolumn{2}{c}{ Collinearity Statistics } \\
& & Tolerance & VIF \\
\hline $1 \quad$ (Constant) & 0,736 & 1,359 \\
& Career & 0,705 & 1,419 \\
& Employee Engagement & 0,766 & 1,306 \\
\hline
\end{tabular}

${ }^{\mathrm{a}}$ Dependent Variable: OCB

Based on the table 3, it can be seen that the regression model does not experience multicollinearity disorder. This can be seen in the tolerance value of each independent variable greater than 0.1. VIF calculation results also show that the VIF value of each independent variable is less than 10. So it can be concluded that there is no multicollinearity between independent variables in the regression model.

\subsection{Heteroscedasticity Test}

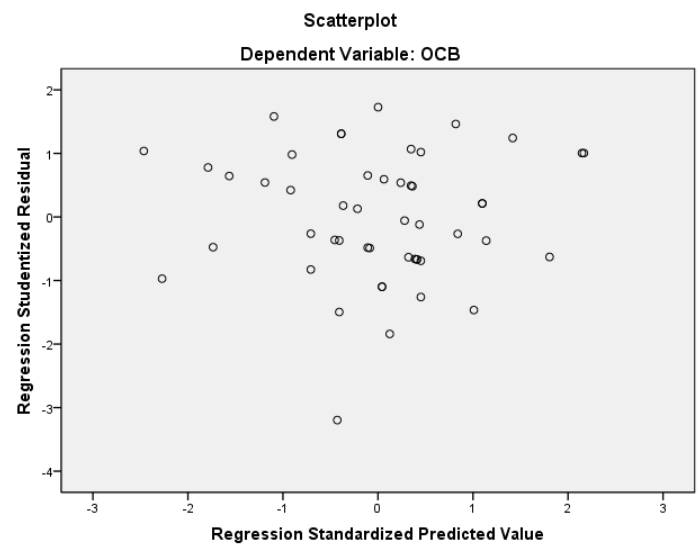

Figure 2 Heteroscedasticity Test

Based on the figure 2, it can be seen that the data distribution is irregular and does not form certain patterns, and is spread above and below the number 0 on the $\mathrm{Y}$ axis, so it can be concluded that in this regression model there is no heteroscedasticity problem.

\subsection{Glejser Test}

Based on the table 5 on the Glejser test above it is said that to strengthen the heteroskedasticity test where the results of the Career variable $\left(\mathrm{X}_{1}\right)$, Employee Engagement $\left(\mathrm{X}_{2}\right)$, Compensation $\left(\mathrm{X}_{3}\right)$ and Organizational Citizenship Behavior (Y) constants of the variable are more of 0.05 (significant ). 
Table 5 Glejser test

Coefficients $^{\mathrm{a}}$

\begin{tabular}{|c|c|c|c|c|c|c|}
\hline & \multirow[t]{2}{*}{ Model } & \multicolumn{2}{|c|}{ Unstandardized Coefficients } & \multirow{2}{*}{$\begin{array}{c}\text { Standardized } \\
\text { Coefficients } \\
\text { Beta }\end{array}$} & \multirow[t]{2}{*}{$\mathrm{t}$} & \multirow[t]{2}{*}{ Sig. } \\
\hline & & B & Std. Error & & & \\
\hline \multirow[t]{4}{*}{1} & (Constant) & 1,368 & 1,497 & & 0,914 & 0,365 \\
\hline & Career & $-0,012$ & 0,068 & $-0,030$ & $-0,175$ & 0,862 \\
\hline & Employee Engagement & $-0,065$ & 0,097 & $-0,117$ & $-0,670$ & 0,506 \\
\hline & Compensation & 0,085 & 0,112 & 0,126 & 0,755 & 0,454 \\
\hline
\end{tabular}

a. Dependent Variable: Abs_RES

4.7 Multiple Linear Regression Analysis

Table 6 Multiple Linear Regression Analysis

Coefficients $^{\text {a }}$

\begin{tabular}{lllllll}
\hline \multirow{2}{*}{ Model } & \multicolumn{2}{c}{$\begin{array}{c}\text { Unstandardized } \\
\text { Coefficients }\end{array}$} & $\begin{array}{l}\text { Standardized } \\
\text { Coefficients }\end{array}$ & T & Sig. \\
& B & Std. Error & Beta & & \\
\hline 1 & (Constant) & 9,919 & 2,654 & & 3,737 & 0,001 \\
& Career & 0,013 & 0,120 & 0,018 & 0,110 & 0,913 \\
& $\begin{array}{l}\text { Employee } \\
\text { Engagement }\end{array}$ & 0,250 & 0,171 & 0,240 & 1,456 & 0,152 \\
& Compensation & 0,193 & 0,199 & 0,153 & 0,969 & 0,337 \\
\hline
\end{tabular}

a. Dependent Variable: OCB

$$
\mathrm{Y}=9,919+0,013\left(\mathrm{X}_{1}\right)+0,250\left(\mathrm{X}_{2}\right)+0,193\left(\mathrm{X}_{3}\right)
$$

With:

$\mathrm{Y}=$ Organizational Citizenship Behavior

$a \quad=$ Constant value

$\mathrm{b}_{1}, \mathrm{~b}_{2}=$ Variable coefficients

$\mathrm{X}_{1} \quad=$ Career

$\mathrm{X}_{2} \quad=$ Employee Engagement

$\mathrm{X}_{3}=$ Organizational Citizenship Behavior

$e \quad=$ error (error term)

1. This constant value of 9,919 shows that Career (X1), Employee Engagement (X2), Compensation (X3) is more than 0.05, then Organizational Citizenship Behavior is 9,919.

2. Career Value (X1) of 0.013. This shows that Career (X1) increases one unit, so the sense of Organizational Citizenship Behavior has less continuity with (Y) of 0.013 less than the Employee Engagement (X2) and Compensation (X3) variables .

3. The coefficient value of Employee Engagement (X2) is 0.250. This shows that employee engagement increases one unit, it will increase the Organizational Citizenship Behavior (Y) by 0.250 which assumes the variable is greater than Career (X1). 
4. Compensation coefficient (X3) value is 0.193 . This shows that compensation increases one unit, it will increase Organizational Citizenship

5. Behavior (Y) of 0.193 which assumes a variable greater than Career (X1).

\subsection{Hypothesis testing}

Table 7 T test

Coefficients $^{\mathrm{a}}$

\begin{tabular}{|c|c|c|c|c|c|c|c|c|}
\hline \multicolumn{2}{|r|}{ Model } & \multicolumn{2}{|c|}{ Unstandardized Coefficients } & \multirow{2}{*}{$\begin{array}{c}\begin{array}{c}\text { Standardized } \\
\text { Coefficients }\end{array} \\
\text { Beta }\end{array}$} & \multirow[t]{2}{*}{$\mathrm{t}$} & \multirow[t]{2}{*}{ Sig. } & \multicolumn{2}{|c|}{ Collinearity Statistics } \\
\hline & & B & Std. Error & & & & Tolerance & VIF \\
\hline \multirow[t]{4}{*}{1} & (Constant) & 9,919 & 2,654 & & 3,737 & 0,001 & & \\
\hline & Career & 0,013 & 0,120 & 0,018 & 0,110 & 0,913 & 0,736 & 1,359 \\
\hline & Employee Engagement & 0,250 & 0,171 & 0,240 & 1,456 & 0,152 & 0,705 & 1,419 \\
\hline & Compensation & 0,193 & 0,199 & 0,153 & 0,969 & 0,337 & 0,766 & 1,306 \\
\hline
\end{tabular}

a. Dependent Variable: OCB

Based on the table 7, data on the $\mathrm{T}$ test (partial) above, it is known that the significant value in the Career variable (X1) is $0.913>0.05$ so the results of the Career variable (X1) significantly influence the Organizational Citizenship Behavior (Y) variable. On Employee Engagement variable (Employee Engagement) (X2) is $0.152<0.05$ so the result is less influential variable on the variables of Organizational Citizenship Behavior (Y). And the Compensation variable (X3) of 0.337> 0.05 so the results of this variable have a significant effect on the variable Organizational Citizenship Behavior (Y). Thus in the variable Career, Employee Engagement (Employee Engagement) and compensation is only one variable that significant influence on Organizational Citizenship Behavior variable (Y) variable Employee Engagement (Employee Engagement) (X2).

\section{Career Variable (X1)}

The $t$ value of the Career variable (X1) obtained a significance value of $0.913>0.05$. This shows that the Career variable (X1) has a partially significant effect on the variable Organizational Citizenship Behavior (Y).

\section{Variable Employee Engagement (Employee Engagement) (X2)}

The $t$ value of Employee Engagement (X2) obtained significance value of $0.152<0.05$. This shows that the variable Employee Engagement (Employee Engagement) (X2) in which no significant effect partially on Organizational Citizenship Behavior variable (Y).

\section{Compensation Variable (X3)}

The $t$ value of Compensation variable (X3) obtained a significance value of $0.337>0.05$. This shows that the Compensation variable (X2) where this variable has a partially significant effect on the variable Organizational Citizenship Behavior (Y). 
Table $8 \mathrm{~F}$ test

\begin{tabular}{|c|c|c|c|c|c|c|}
\hline \multicolumn{7}{|c|}{ ANOVA $^{b}$} \\
\hline & Model & Sum of Squares & Df & Mean Square & $\mathrm{F}$ & Sig. \\
\hline \multirow[t]{3}{*}{1} & Regression & 20,279 & 3 & 6,760 & 2,081 & $0,116^{a}$ \\
\hline & Residual & 149,401 & 46 & 3,248 & & \\
\hline & Total & 169,680 & 49 & & & \\
\hline
\end{tabular}

a. Predictors: (Constant), Compensation, Career, Employee Engagement

b. Dependent Variable: OCB

Based on the table above on the $\mathrm{F}$ test (simultaneous) above, it can be said that the $\mathrm{F}$ test results simultaneously with an $F$ count of 2. 081 with a significant level of 0.116 . A significant value of $F$ greater than 0.05 means more able to have a significant simultaneous effect on the Career (X1), Employee Engagement (X2), Compensation (X3) and Organizational Citizenship Behavior (Y) variables.

\section{Discussion}

\subsection{Career Influences on Organizational Citizenship Behavior}

The first hypothesis proposed states that Careerthas a significant effect on Organizational citizenship behavior, partially this has been proven by the results of the $\mathrm{T}$ test 0.913 . This is consistent with the responses of respondents because the results are rational. Respo nden give right response to that career provided the company that do not conform to their expectations.

In all nyataan yes, influence is not significant in the career of the Organizational Citizenship B ehavior can be clarified with the results of the analysis of multiple linear regression. Analysis of multiple linear regression also indicates that each increase of one unit of Kar ir then Oganisasional Citizenship B ehav ior how berpen garuh against (Y) by 9, 913. It means that the greater the career, then there is a significant influence on the change in Organizational Citizenship Behavior.

\subsection{The Effect of Employee Engagement on Organizational Citizenship Behavior}

The second proposed hypothesis states that the involvement of employees (employee engagement) does not affect signi fikan against Organizational C tizenship B ehavior, due partially it has terbu KTI with $0.152 \mathrm{~T}$ test results . This is consistent with the responses of respondents because the results are rational. R ESPO nden provide feedback that $\mathrm{K}$ eterli ty employees provided the company in accordance with their expectations.

In fact, the lawyer aruh were not significant in Employee Engagement against Organizational citizenship behavior can be clarified with the results of multiple linear regression analysis. Multiple linear regression analysis also indicates that each increase of one unit of Employee Engagement then Organizational Citizenship B ehavior very ber influence on the (Y) of 0,152. Mean more smaller Employee Engagement (Employee Engagement) then there is no significant effect amendments to the organizational citizenship behavior.

\subsection{Effect of Compensation on Organizational Citizenship Behavior}

The third hypothesis proposed states that Compensation has a significant effect on Organizational Citizenship Behavior, partially this has been proven by the result of the T test of 0.337 . This is consistent with the 
responses of respondents because the results are rational. Respondents gave responses that the compensation given by the company was in accordance with what was expected by them.

In fact, a significant effect in Compensation on Organizational Citizenship Behavior can be clarified with the results of multiple linear regression analysis. Multiple linear regression analysis also indicates that for every increase in one unit of compensation the organizational citizenship behavior is very influential on (Y) of 0.337. Means that the greater the Compensation, the very significant influence of the change on Organizational Citizenship Behavior.

\subsection{Career Influence, Employee Engagement and Compensation for Organizational Citizenship Behavior}

The fourth hypothesis states that Career has a significant effect on Organizational Citizenship Behavior, while Employee Engagement has less influence on Organizational Citizenship Behavior and Compensation variables have a significant effect on Organizational Citizenship Behavior. This is evident from the calculated $F$ test results of 0.337 with a significant level of $0,116^{2}$. A significant value of $\mathrm{F}$ greater than 0.05 means more able to have a significant effect on all of these variables.

In the above reality for the influence of the Career variable, Employee Engagement is less influential on Organizational Citizenship Behavior and Compensation has an important effect on Organizational Citizenship Behavior in the company.

\section{Conclusions and recommedation}

\subsection{Conclusion}

Based on the analysis that has been done, some conclusions can be drawn as follows:

1. The results of data processing using SPSS shows the Career variable partially influences Organizational Citizenship behavior, with $\mathrm{T}$ test results greater than 0.05 .

2. Variable Employee Engagement (Employee Engagement) less influential partially on Organizational Citizenship Behavior with $\mathrm{T}$ test result of $0.152<0.05$.

3. Results that have been tested in data processing using SPSS on the Compensation variable partially have a significant effect on Organizational Citizenship Behavior with T test results of 0.337>0.05.

\subsection{Recommedation}

Based on the conclusion above, the writer gives some suggestions which are expected to be beneficial for PT. Wika Intinusa Surabaya is as follows :

1. Based on the results of data processing, the company needs policies - policies on career variables to increase the potential of employees who have worked long enough in the company.

2. For further research is expected to enter and add other variables as independent variables, so research se lanjutn yes that will be done will be able to know variabe 1-variebel another very affecting Organizational Citizenship Behavior in peru sahaan PT. Wika Intinusa Surabaya . It is important dilakuka $n$ because of the results of research by the author, it turns variable - independent variables studied were composed of variables to be studied by other researchers, namely variable Organizational Commitment, Job Satisfaction, and Organizational Culture Career Clarity .

\section{References}

Al-Shawabkeh, KM (2017). Career Path Development and its Impact on Organizational Citizenship Behavior in Greater Amman Municipality. International Journal of Business and Management, 12 (3), 79. https://doi.org/10.5539/ijbm.v12n3p79 
Achmad Kuncoro, Engkos. And Riduwan. 2008. How to use and interpret Path Analysis. Bandung: Alfabeta.

Bagus Danendra, A., \& Mujiati, N. (2016). Effects of Motivation, Compensation and Organizational Commitment on Organizational Citizenship Behavior (Ocb). E-Journal of Management of Udayana University, 5 (10), 62296259.

Devi, D., \& Adnyani, I. (2015). Effect of Employee Job Satisfaction on Organizational Commitment and Organizational Citizenship Behavior (Ocb) at Pt. Maharani Prema Sakti Denpasar. E-Journal of Management of Udayana University , 4 (12), 4105-4134.

Dhanda, U. (2015). Employee Engagement: the Key Success Factor. International Journal of ResearchGranthaalayah, 3 (5), 77-87.

Dalil, S. 2002. New Paradigm in Human Resource Management. Yogyakarta: Amara Book.

Henry, Simamora. 2004 . Human Resource Management . 3rd Edition. STIE YKPN. Yogyakarta.

Husein, Umar. (2000). Research Methodology, Application in Marketing, Jakarta: PT. Gramedia Main Library.

Haeruddin, MIM (2017). Effect of Salary and Incentives on Employee Performance and Organizational Citizenship Behavior (OCB) at the Grand Clarion Hotel in Makassar. Economic and Business Management Applications , 2 (1), 11-21.

Naway, FA, \& Haris, I. (2017). The Effect of Career Development, Perception of Organizational Justice and Job Satisfaction on Teacher's Organizational Citizenship Behavior. International Review of Management and Marketing , 7 (2), 17-21.

Nielsen. 2012. The Nielsen Global Survey of E-Commerce. http://www.nielsen.com/us/en/insights/reports/2014/ecommerce-evolutionor-revolution-in-the-fast-moving-consumer-goods-world.html, 29 December 2016

Organ, DW ,. et al. (2006). Organizational Citizenship Behavior. Its Nature, Antecendents, and Consequences. California: Sage Publications, Inc.

Partial Least Square PLS , 3rd ed. Diponegoro University Publisher Agency.

Prabasari, IGAM, Martini, LKB, \& Suardika, N. (2018). The Effect of Communication and Employee Engagement on Organizational Citizenship Behavior and Employee Performance in Employees Pt. Pln (Persero) Distribution of Bali. International Journal of Contemporary Research and Review,9(08), 2101421025. https://doi.org/10.15520/ijcrr/2018/9/08/586

Program, M., Masters, S., Public, A., University, P., Program, D., Masters, S., ... University, P. (nd). PEGAWAI IN THE PUBLIC WORK SERVICE OF THE PALU CITY . 147-158.

Ravikumar, T. (2013). A Study on the Impact of Team Work, Work Culture, Leadership and Compensation on Engagement Levels of Employees in MSMEs in India. International Journal of Advanced Research in Management and Social Sciences , 2 (8), 175-185.

Robbins, SP (2008). Organizational Citizenship Behavior. In Organizational Behavior . Salemba Empat.

Robbins and Judge. (2008). Organizational Behavior . Salemba Empat, Jakarta.

Robinson, D., Perryman, S., \& Hayday. (2004). The Drivers of Employee Engagement Report 408. Brington: Institude for Employment Studies.

Solichin, MR (2018). Analysis of the Effect of Employee Engagement, Emotional Intelligence, and Commitment to Organizational Citizenship Behavior (OCB) on Employees of PO Efficiency Kebumen Branch Much. Riyadus Solichin Management Study Program, STIE Putra Bangsa Kebumen. Journal of Economics and Informatics Engineering , 6 (2), 36-47.

Sugiyono, 2013, Quantitative, Qualitative, and R\&D Research Methodology. (Bandung: ALFABETA) 
Sugiyono 2013. Educational Research Methods Quantitative, Qualitative, and R\&D Approaches. Bandung: Alfabeta.

Wulandari, AD, \& Yuniawan, A. (2017). Analysis Of The Influence Of Organizational Support And Career Development To Behavior Organizational Citizensip With Employee Engagement As Intervening Variables (Study of PDAM Tirta Moedal Employees in Semarang City). In Iponegoro Journal of Management , 6, 1-14.

Wahyuddin, Purwanto, 2011. The Effect of Job Satisfaction Factors on the Performance of IMKA Accounting Education Employees in Surakarta. Graduate program. Surakarta: Muhammadiyah University Surakarta. 